treatment may be supplied by an enriched high calorie oral diet, supplemented in the patients with the most extensive burns by intravenous infusions of fat emulsions and solutions of carbohydrates and amino acids.

Adoption of these methods of treatment has been followed by the survival of three patients with very extensive burns and an absence of a 'stress reaction' in all the other patients treated in the warm, dry environment.

\title{
REFERENCES
}

Barr, P.-O., Birke, G., Liljedahl, S.-O. \& Plantin, L.-O. (1968). Lancet i, I64.

Bull, J. P. \& England, N. W. J. (1954). Lancet ii, 9.

Caldwell, F. T., Osterholm, J. L., Sower, N. D. \& Moyer, C. A. (r959). Ann. Surg., 150, 976.

Cope, O.\& Moore, F. D. (1947). Ann. Surg. 126, 1010.

Cuthbertson, D. P. \& Tilstone, W. J. (r968). Am. F. clin. Nutr. 2x, 9г 1.

Davies, J. W. L. (1967). Clin. Sci. 32, 101.

Davies, J. W. L., Liljedahl, S.-O. \& Birke, G. (1969). Injury I, 43.

Davies, J. W. L. \& Liljedahl, S.-O. (1970). In Energy Metabolism in Trauma, Ciba Foundation Symposium, p. 59 [R. Porter and J. Knight, editors]. London: J. \& A. Churchill.

Davies, J. W. L. \& Liljedahl, S.-O. (197I). In Contemporary Burn Management. Boston, USA: Little, Brown \& Co. (In the Press.)

Harrison, H. N., Moncrief, J. A., Duckett, J. W. Jr \& Mason, A. D. (1964). Surgery, St Louis 56, 203. Lamke, L.-O., Körlof, B., Liljedahl, S.-O. \& Nylén, B. (197I). In Research in Burns p. 526 [P. Matter, T. L. Barclay and Z. Koničková, editors]. Berne: H. Huber.

Roe, C. F. \& Kinney, J. M. (1964). Surgery, St Louis 56, 212.

Zawacki, B. E., Spitzer, K. W., Mason, A. D. \& Johns, L. A. (1970). Ann. Surg. 171, 236.

\section{Metabolism after surgery in the elderly}

By W. F. Walker, Arleen Watt, H. G. Morgan* and J. Parker, Department of Surgery, Royal Infirmary, Dundee

\section{Introduction}

The geriatric population of the western world is increasing. We are faced, therefore, more and more with the need to perform major operations on elderly patients, many of whom are suffering from disorders of the cardiovascular, respiratory and renal systems. These may either limit the extent of surgery or make convalescence stormy. These patients present a challenge to all of us which can only be met by an extensive knowledge of their medical problems and their responses to operations. Surgery may affect not only the systems already mentioned, but also produce its own effects on body metabolism. It is often said that age affects the metabolic response to surgery as does the severity of trauma. We were unable to find a detailed study of these two factors in elderly patients and we felt it worth while to investigate the problem further.

\section{Methods}

Full metabolic balance studies were done in fifteen patients aged 60-79 years of age, of both sexes, who were subjected to operation. The patients were selected *Present address: Department of Pathological Biochemistry, Royal Infirmary, Glasgow $\mathbf{C}_{4}$. 
Vol. $3^{\circ}$

Nutrition after injury

I73

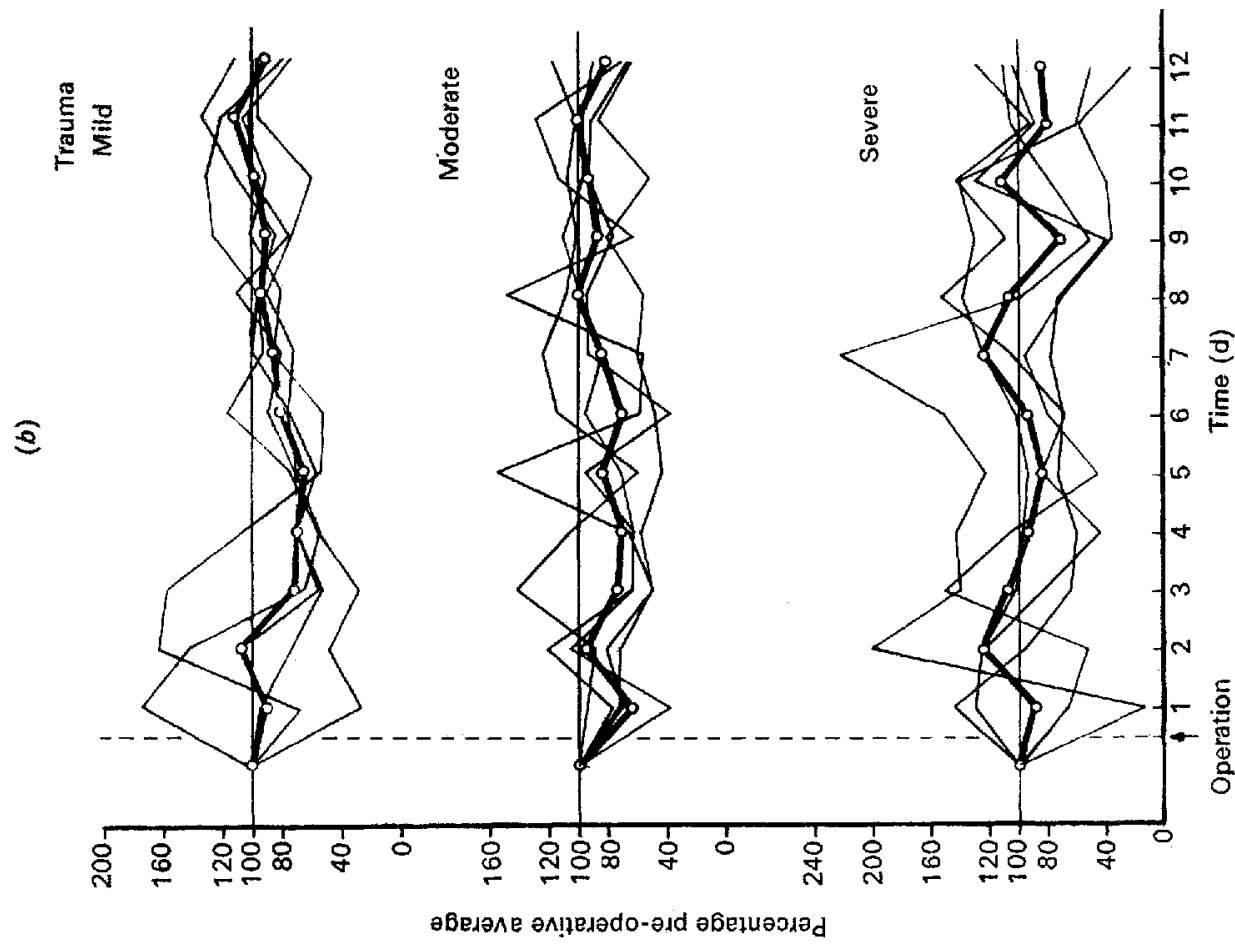

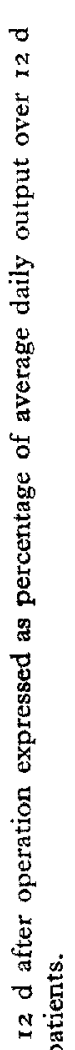

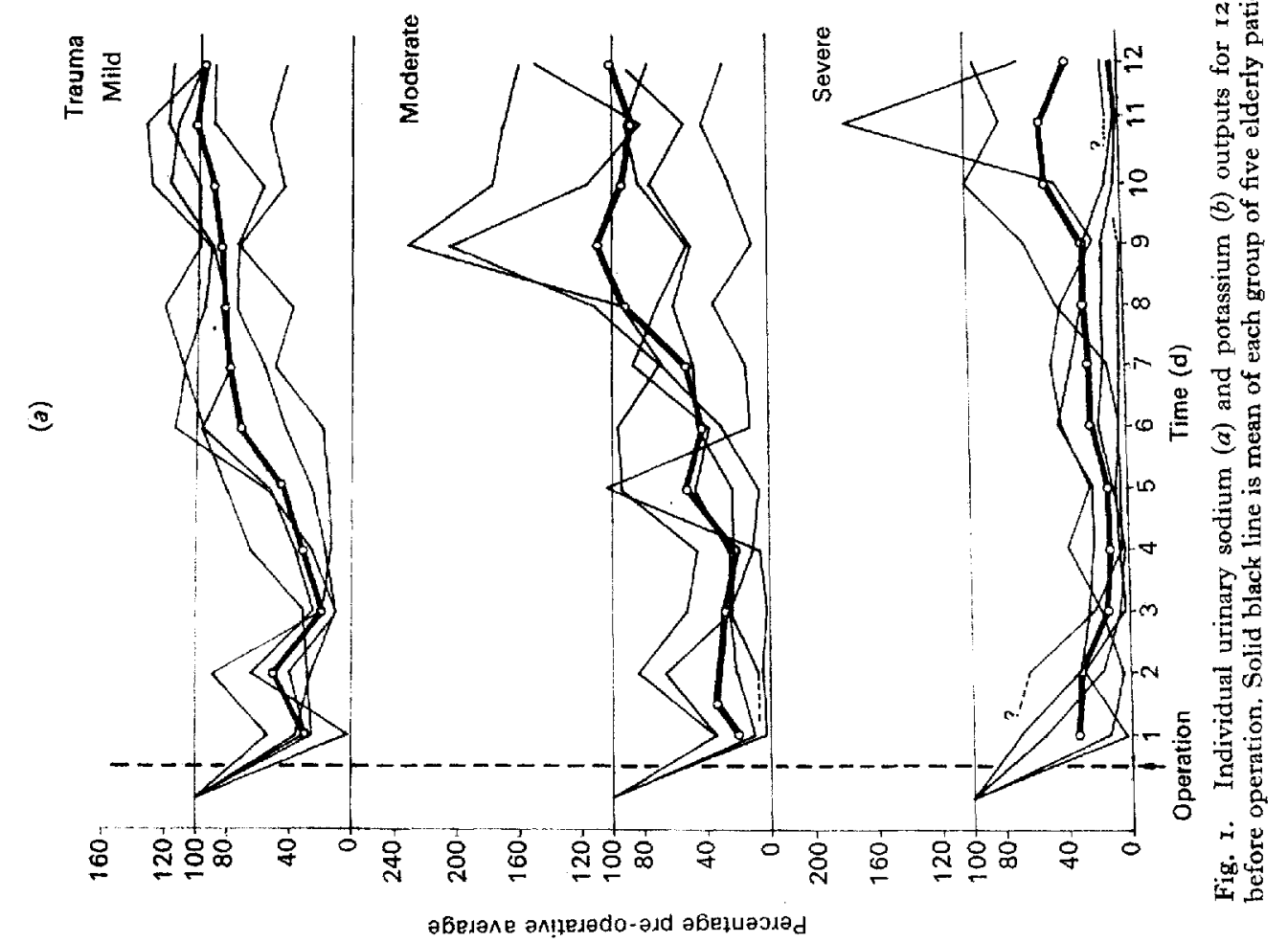


randomly, the only criteria being those of good nutritional status and the absence of overt cardiac, respiratory or renal disease. A subdivision was made into three groups of five, classified as 'mild', 'moderate' and 'severe' according to the degree of trauma involved in the operation. This grading was done by the one surgeon who performed all the operations. Mild trauma included appendicectomy, herniorrhaphy and excision of fistula-in-ano. Moderate trauma included lumbar sympathectomy, cholecystectomy, and vagotomy with gastro-enterostomy. Severe trauma included hemicolectomy, abdominoperineal resection of the rectum and partial gastrectomy.

Balance technique and chemical methods. The balance technique has been fully described in a previous paper which dealt mainly with calcium and phosphorus metabolism (Walker, Watt, Morgan \& McCowan, 1964). Great care was taken to empty the lower bowel every 6th day to demarcate four periods, two before and two after operation. The effectiveness of the pre-operative bowel washouts was detected at operation.

\section{Results}

Urinary excretion. In illustrating the renal excretion of nitrogen and the ions in the three groups of patients, we took the average daily excretion in the pre-operative period as $100 \%$ and recorded the daily excretion after operation as a percentage of this. In this way each patient acts as his own control and the trend in the groups of patients can be more easily contrasted. The fall in sodium excretion (Fig. $\mathrm{r} a$ ) is evident after all grades of trauma but was more pronounced and lasted longer in the severe group. Increased excretion of potassium (Fig. $\mathrm{I} b$ ) was present in the Ist day

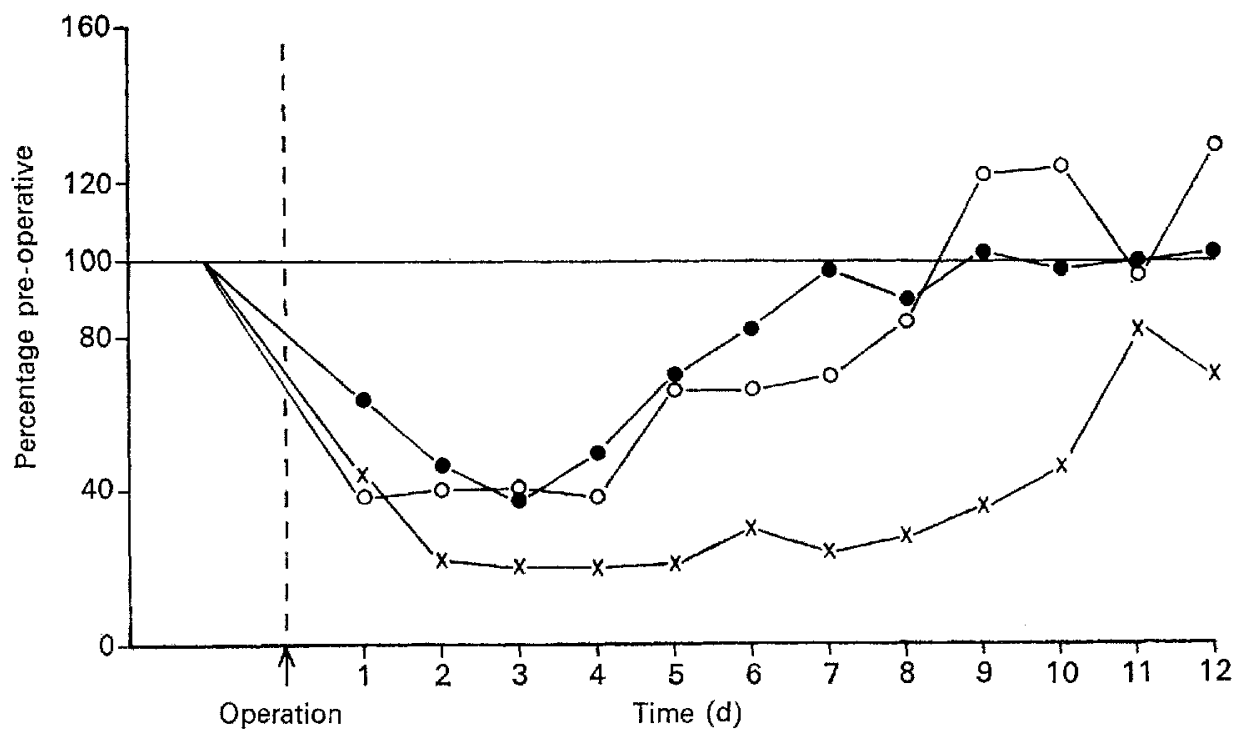

Fig. 2. Mean ratios of urinary $\mathrm{Na}: \mathrm{K}$ in the three groups of elderly patients after operation. mild trauma; $O-O$, moderate trauma; $x-\times$, severe trauma. 
Vol. 30

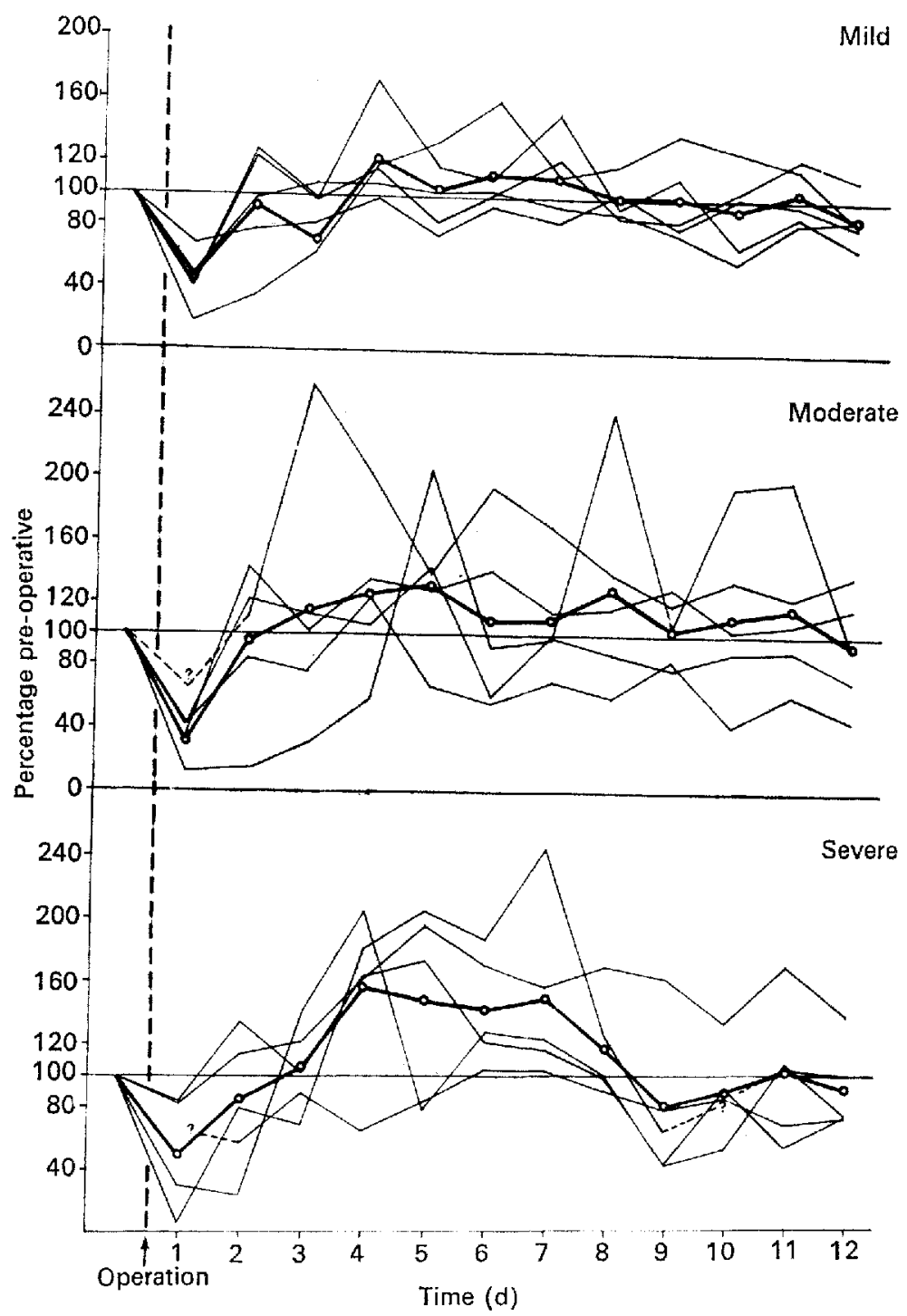

Fig. 3. Individual urinary nitrogen outputs for $12 \mathrm{~d}$ after operation expressed as percentage of average daily output over $12 \mathrm{~d}$ before operation. Solid black line is mean of each group of five elderly patients.

after mild trauma and increased with the severity of the trauma. The average $\mathrm{Na}: \mathrm{K}$ ratio of these two ions is shown in Fig. 2. If this ratio is accepted as an index of adrenocortical secretion, then increased activity was present with increasing severity of trauma. Even I 2 d after operation the ratio was only back to normal in one patient.

The increase in $\mathrm{N}$ excretion (Fig. 3 ) occurred from the 2 nd day onward, being more obvious and more prolonged in the severe trauma group. Details of the urinary excretion of $\mathrm{Ca}$ and $\mathrm{P}$ have been given previously (Walker et al. 1964). The very close relation of $\mathrm{Ca}$ and $\mathrm{Na}$ excretion, both in degree and in duration, was 


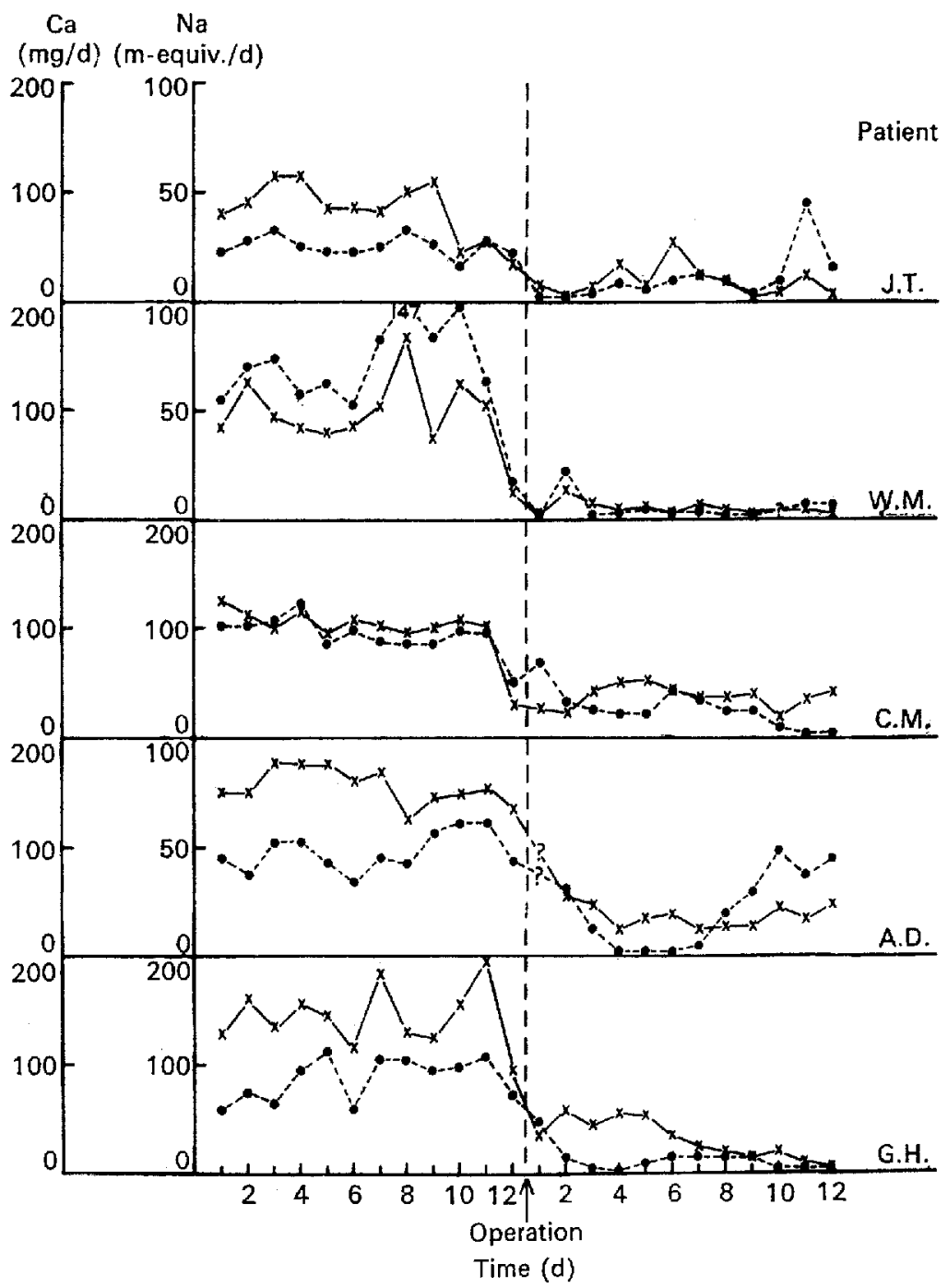

Fig. 4. Correlation in individual elderly patients of the severe trauma group between urinary outputs of sodium $(x-x)$ and calcium $(-\ldots)$.

unexpected. This correlation of reduced urinary $\mathrm{Ca}$ and $\mathrm{Na}$ occurred in all three groups, but was most evident in the severe group (Fig. 4). Magnesium excretion, on the other hand, was decreased immediately after operation but rose to normal levels or, in some patients above normal in the next $24-48 \mathrm{~h}$. This pattern correlates well with that of $\mathrm{N}$ excretion.

Balances. Balance data are shown in Fig. 5 as averages for the three groups of patients. In the minor trauma group (Fig. 5 a) there is, as might be expected, only a minor metabolic response to trauma with a slight retention of $\mathrm{Na}$, a slight loss of $\mathrm{K}$, and a slight and early negative balance of $\mathrm{N}$ and $\mathrm{P}$. In the moderate trauma group (Fig. $5 b$ ), the changes are more evident, and after severe trauma (Fig. $5 c$ ) they are 
Vol. 30

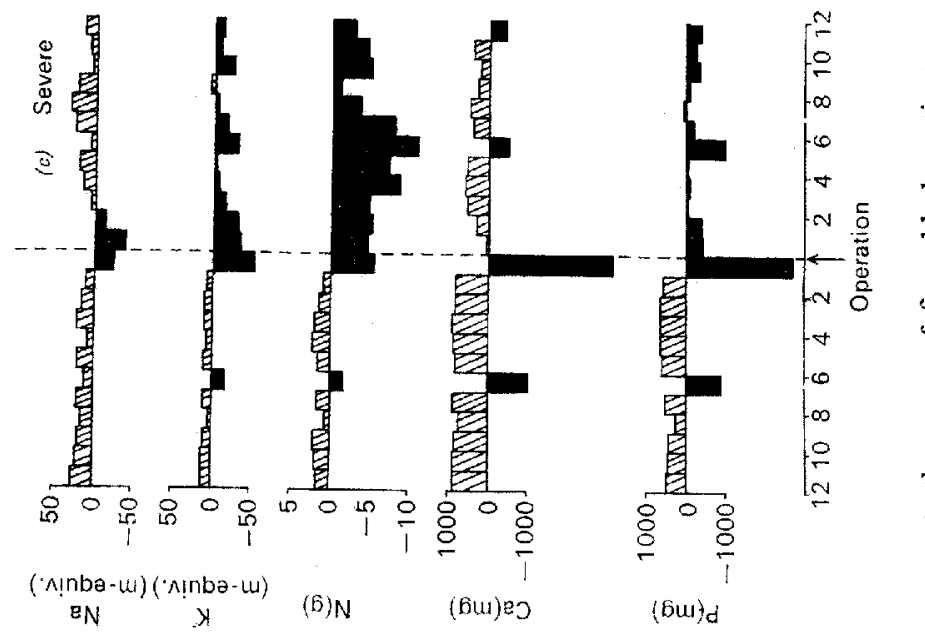

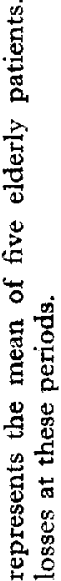

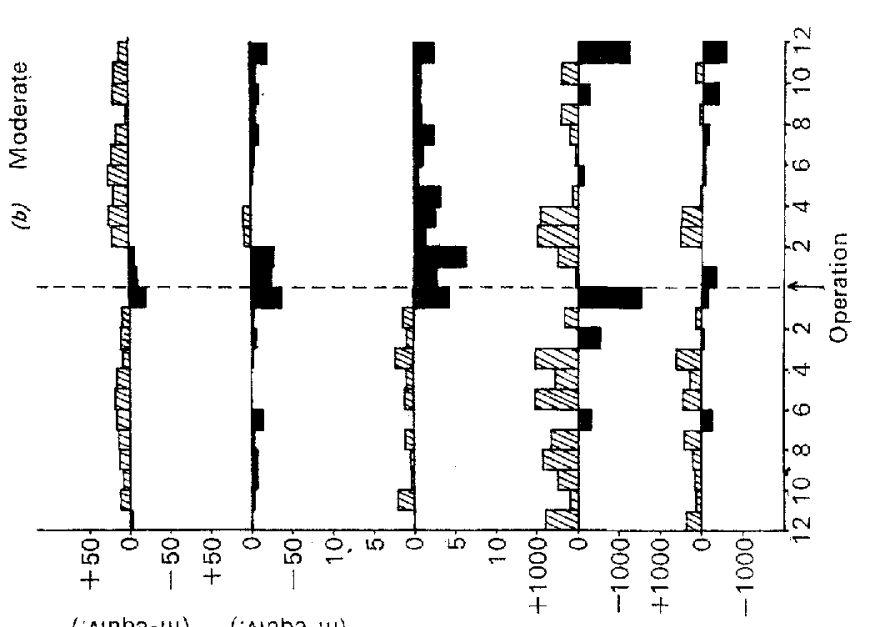

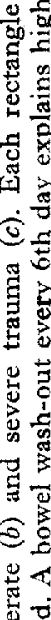

$\begin{array}{cc}\text { (A!nbo-u) } & \text { (A!nbə-w) } \\ \text { EN } & x\end{array}$

(B) N

(6u) es

(6u)d
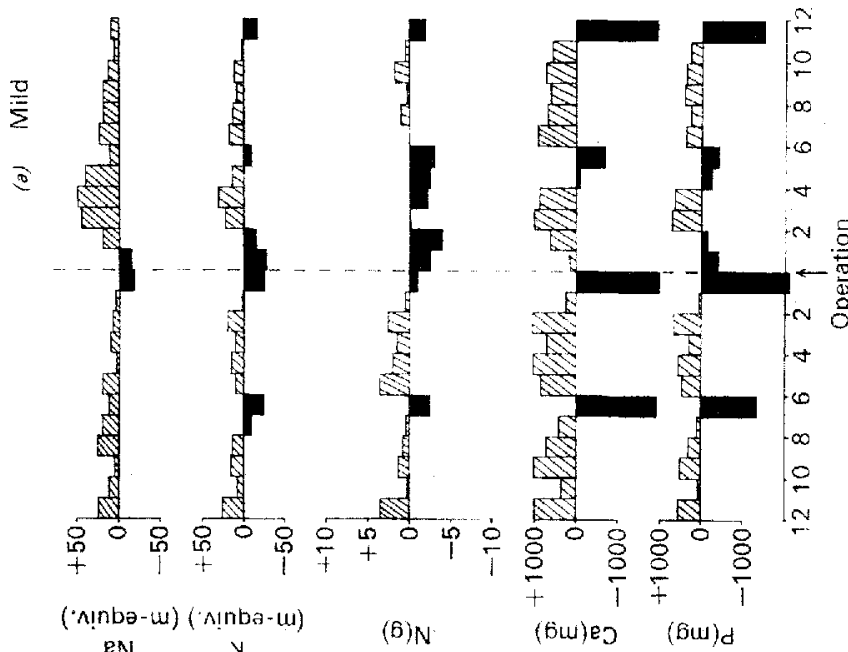

\&

范

घ

赹范

$8:$

ब.

岁

공

("n!nbə-w) (n!nba-m)

(6) N

(bu)es (bu)d

的雚 
not only more pronounced but also of longer duration. In all groups the Ca conservation is noteworthy, the response being similar to that of $\mathrm{Na}$. The numerical data of the unchanged $\mathrm{Ca}$ balance, and of $\mathrm{P}$ and $\mathrm{N}$ losses have been documented in detail by Walker et al. ( 1964$)$.

The $\mathrm{N}$ loss after severe trauma amounted to an average daily loss of $6.6 \mathrm{~g}$ for the first 6 -d period after operation. This is equivalent to nearly $1 \cdot 2 \mathrm{~kg}$ of lean tissue lost over $6 \mathrm{~d}$. The loss continued over the second $6-\mathrm{d}$ period at the rate of $4.4 \mathrm{~g} \mathrm{~N} /$ $\mathrm{d}$ or $0.8 \mathrm{~kg}$ of lean tissue over the second $6-\mathrm{d}$ period. The total average loss of lean tissue in this group over the $12 \mathrm{~d}$ was $2.0 \mathrm{~kg}$.

\section{Discussion}

Elderly in the sense of years is not necessarily so in biological terms. It is a common clinical finding that many a geriatric patient has the body and mind of someone from a younger generation and some men in their 40's are biologically much older. Disease, especially atheroma, ages the tissues. Our selection of patients was an attempt to eliminate the difficult problem of relative ageing of the body. Though there was no gross disorder present other than the one necessitating operation, we cannot conclude that disease processes were not at work. It is probable that some of the patients were at the lower limit of normality with regard to organ function and that the added stress of operation was enough to tip them into some degree of organ failure. This was certainly true of one patient in the severe trauma group: his blood urea rose to $r 80 \mathrm{mg} / \mathrm{r} 00 \mathrm{ml}$ and remained elevated for about $8 \mathrm{~d}$. Creatinine clearances were done in a number of the patients and a fall occurred immediately after operation with a rapid return to normal. This temporary depression in renal function is usual after any operation and almost invariable after a major operation.

Diminished pulmonary function is also common in elderly patients who therefore require to work harder to obtain the necessary oxygen intake - a factor which may have its effect on body metabolism.

Apart from these factors of disordered function, there is the possible effect of changes in body composition. The total body water in the eighth decade may have fallen to $50 \%$ of the body-weight. The extracellular fluid increases with age and the intracellular fluid falls (Parker, Oleson, McMurdy \& Friis-Hansen, 1958). The major change in the electrolytes is a decrease in total exchangeable $\mathrm{K}$ which indicates a reduction in the metabolically active cell mass.

In our patients the urinary excretion of the various substances illustrates well the effect of increasing severity of trauma. Na-retention was unusually prolonged when compared with the response in younger subjects (unpublished observation). This may be due to prolonged aldosterone secretion which is supported by the $\mathrm{Na}: \mathrm{K}$ ratio seen in Fig. 2. It would appear that there was active adrenocortical function undiminished by age. It may be that the cardiovascular function in the elderly is less stable and that severe trauma leads more easily to hypotension with stimulation of the renin-angiotensin system and secretion of aldosterone. If this were so then it may afford a clue with regard to the compositional changes with age of $\mathrm{K}$ loss and 
retention of water. The prolongation of Na-retention was closely correlated with a considerable decrease in urinary $\mathrm{Ca}$. The action of the Na-retaining steroids and the mechanisms of the interaction between $\mathrm{Na}$ and $\mathrm{Ca}$ excretions are not straightforward (Wills, Gill \& Bartter, 1969; Antoniou, Eisner, Slotkoff \& Lilienfield, 1969).

The $\mathrm{N}$ response following trauma was typical but rather prolonged. There was no sign of protein depletion prior to operation even in the patients with cancer. Earlier work by Abbott, Krieger 8 Levey ( $\left.195^{8}\right)$ demonstrated that parenteral nutrition could diminish the $\mathrm{N}$ response provided calories were given with the amino-acid solutions and this was confirmed by similar studies in this country (Walker, 1960). The prolonged $\mathrm{N}$ response in these elderly patients may suggest that intravenous fat and protein might be beneficial. Although there is no question that elderly patients take a much longer time to get over the weakness following a major operation, it is doubtful whether parenteral feeding would do much to improve this.

The conservation of $\mathrm{Ca}$ is of considerable interest and is difficult to explain, both in the possible implications of unchanged skeletal turnover and the reduced urinary $\mathrm{Ca}$, despite a largely maintained intake, normal plasma levels and good renal function. Previous workers have shown some loss of $\mathrm{Ca}$ after bony injury (Cuthbertson, I930) and after soft tissue injury (Peddie, Spurr \& Howard, 1956; Mark \& Hayes, 196r). Our own findings confirm others with respect to children and adults (unpublished observations), but in the elderly we find a new situation, that of conservation. A possibility, as yet unproved, is that $\mathrm{Ca}$ behaves in a way similar to $\mathrm{N}$. It has been shown that if animals (Fleck \& Munro, I963) and man (Abbott \& Albertsen, I963) are depleted of protein, there is a minimal increase, if any, in $\mathrm{N}$ excretion after operation. Are then the elderly depleted of $\mathrm{Ca}$ (Anderson, Campbell, Dunn \& Runciman, 1966) and therefore unable to respond by losing more $\mathrm{Ca}$ ?

The increased Mg output after operation that was found in some patients occurred at a time when the intake was nil and it therefore represents a real loss of $\mathrm{Mg}$ by the body. Post-operative loss of $\mathrm{Mg}$ has been observed in patients of all ages and is part of the metabolic response to trauma (Walker, Fleming \& Stewart, I968); the loss is thought to represent cell breakdown or a shift of the ions from the cells.

\section{REFERENCES}

Abbott, W. E., Krieger, H. \& Levey, S. (1958). Lancet i, 7o5.

Abbott, W. E. \& Albertsen, K. (1963). Ann. N.Y. Acad. Sci. 110, 941.

Anderson, I., Campbell, A. E. R., Dunn, A. \& Runciman, J. B. M. (1966). Scott. med. F. ri, 429.

Antoniou, L. D., Eisner, G. M., Slotkoff, L. M. \& Lilienfield, L. S. (1969). F. Lab, clin. Med. 74, 410.

Cuthbertson, D. P. (1930). Biochem. F. 24, 1244.

Fleck, A. \& Munro, H. N. (1963). Metabolism 12, $78_{3}$.

Mark, J. B. D. \& Hayes, M. A. (196r). Surgery Gynec. Obstet. 113, 213.

Parker, H. V., Oleson, K. H., McMurdy, J. \& Friis-Hansen, B. (1958). In Ciba Colloquia on Ageing Vol. 4, p. 102 [G. E. W. Wolstenholme and M. O'Connor, editors]. London: J. \& A. Churchill.

Peddie, G. H., Spurr, C. L. \& Howard, J. M. (1956). Ann. Surg. 143, 452.

Walker, W. F. (1960). Proceedings of a Symposium on Wound Healing and Tissue Repair. St Andrews University.

Walker, W. F., Watt, A., Morgan, H. G. \& McCowan, M. A. A. (1964). Br. F. Surg. 5x, 783.

Walker, W. F., Fleming, L. F. \& Stewart, W. K. (1968). Br. F. Surg. 55, 466.

Wills, M. R., Gill, J. R. \& Bartter, F. C. (1969). Clin. Sci. 37, 621. 